\title{
CORRIGENDUM \\ Genetic differentiation and admixture between sibling allopolyploids in the Dactylorhiza majalis complex
}

\author{
F Balao, M Tannhäuser, MT Lorenzo, M Hedrén and O Paun \\ Heredity (2017) 118, 210; doi:10.1038/hdy.2016.119; published online 7 December 2016
}

Correction to: Heredity (2016) 116, 351-361; doi:10.1038/hdy.2015.98; published online 25 November 2015

Updated online 30 November 2016: This article was originally published under a CC BY-NC-SA 4.0 license, but has now been made available under a CC BY 4.0 license. The PDF and HTML versions of the paper have been modified accordingly. (c) (i)

This work is licensed under a Creative Commons Attribution 4.0 International License. The images or other third party material in this article are included in the article's Creative Commons license, unless indicated otherwise in the credit line; if the material is not included under the Creative Commons license, users will need to obtain permission from the license holder to reproduce the material. To view a copy of this license, visit http:// creativecommons.org/licenses/by/4.0/

(C) The Author(s) 2017 